\title{
Citizenship Deprivation as a Counterterrorism Measure in Europe; Possible Follow-Up Scenarios, Human Rights Infringements and the Effect on Counterterrorism
}

\author{
Maarten P. Bolhuis and Joris van Wijk \\ Assistant Professor respectively Associate Professor, Center for International \\ Criminal Justice, Department of Criminal Law and Criminology, Faculty of \\ Law, VU University, Amsterdam, The Netherlands \\ m.p.bolhuis@vu.nl;j.van.wijk@vu.nl
}

\begin{abstract}
The departure of substantial numbers of 'foreign fighters' and the occurrence of terrorist attacks on European soil have prompted renewed interest in citizenship deprivation as a policy measure. This article aims to contribute to the debate on its utility as a counterterrorism measure by examining recent developments in citizenship deprivation legislation and its use in Belgium, France, Germany, the Netherlands and the UK; discussing the wide array of possible scenarios that may follow after an individual is deprived of citizenship; and analysing to what extent the various outcomes are instrumental in countering terrorism. It concludes that most of the outcomes are problematic from a human rights perspective, or counterproductive in the fight against terrorism as they may cause further marginalisation and radicalisation and can play into the hands of terrorist groups, may cause people to disappear from the radar, and may undermine crucial international cooperation.
\end{abstract}

\section{Keywords}

citizenship deprivation - foreign fighters - counterterrorism - deportation statelessness - radicalisation - legal limbo 


\section{Introduction}

The departure of substantial numbers of 'foreign fighters'-citizens from European countries travelling to Islamic State (IS)-controlled territories in Iraq and Syria - and the occurrence of terrorist attacks on European soil, have prompted renewed interest in citizenship deprivation as a policy measure. Especially since the fall of IS in 2019, a fierce debate has emerged on what to do with foreign fighters who are still (believed to be) in Iraq and Syria. While there have been calls upon European states to repatriate those foreign fighters in Kurdish and US captivity and deal with them in the domestic criminal justice system, most European states have so far refused to bring 'their' foreign fighters back. Rather, there are clear indications that European governments do what is in their power to prevent foreign fighters from returning, making use of legislative reforms that have expanded deprivation powers in recent years, or initiating new reforms to prevent a similar situation in the future. This represents a sharp policy turn from the past decades, when European states used expatriation with great hesitance. ${ }^{1}$ Apart from symbolic justifications appealing to the public perception that involvement in terrorism is proof of disloyalty to the state, politicians have used the counter-terrorism or national security paradigm to justify the expansion of deprivation powers. ${ }^{2}$ However, academics and civil society have criticized the expansion of deprivation powers very firmly. The academic discussion focuses on the compatibility of expanded powers with international nationality and human rights law, ${ }^{3}$ the changing

1 Esbrook, L. (2016). Citizenship Unmoored: Expatriation As A Counter-Terrorism Tool, University of Pennsylvania Journal of International Law 37(4), pp. 1273-1329, at p. 1275.

2 Van Waas, L. (2016). Foreign Fighters and the Deprivation of Nationality. National Practices and International Law Implications, in: A. de Guttry et al. (eds), Foreign Fighters under International Law and Beyond, The Hague: T.M.C. Asser Press, pp. 469-487; Fargues, E. (2017). The revival of citizenship deprivation in France and the UK as an instance of citizenship renationalisation, Citizenship Studies 21(8), pp. 984-998; Pillai, S. \& Williams, G. (2017). The Utility of Citizenship Stripping Laws in the UK, Canada and Australia, Melbourne University Law Review 41, pp. 845-889.

3 Apart from Esbrook (2016) and Van Waas (2016), e.g. Zedner, L. (2016). Citizenship Deprivation, Security and Human Rights. EMIL 18(2), pp. 222-242; Mantu, S. (2018). 'Terrorist' Citizens and the Right to Nationality. Journal of Contemporary European Studies 26(1), pp. 28 41; Reyntjens, L. (2019). Citizenship Deprivation under the European Convention-System: A Case Study of Belgium, Statelessness \& Citizenship Review 1(2), pp. 263-282. 
perception on the concept of citizenship and its broader consequences, ${ }^{4}$ and the instrumental value or utility of the measure in the fight against terrorism. ${ }^{5}$

In respect of the latter, an assumption often made in political rhetoric is that citizenship deprivation will keep the expatriated individual, who poses a security risk, out of the country's territory and in that way benefits the national security of the individual state. However, whether this policy measure actually contributes to countering terrorism - on the longer term and also beyond the level of the individual state-is strongly disputed in the literature. ${ }^{6}$ For example, the measure may lead to further marginalization and radicalization, and may drive people back to terrorist groups, rather than away from them, ${ }^{7}$ which may backfire on the security of the individual state, as well as other states. This article aims to contribute to the debate on the utility of citizenship deprivation as a counterterrorism measure by discussing the wide array of possible scenarios that may follow after an individual is deprived of citizenship, and by analysing whether and to what extent the various outcomes are instrumental in countering terrorism. It does so by i) examining recent developments in the scope of citizenship deprivation legislation, and its use against individuals (allegedly) involved in terrorism, and ii) discussing what is known about the immigration law consequences of citizenship deprivation for the individuals concerned, as well as for the depriving state, the state of residual nationality, and third states. It focuses on five European countries (Belgium, France, Germany, the Netherlands and the United Kingdom) and is based on an extensive review of academic literature, policy documents and available case law, and media reporting. All selected countries have a considerable number of (returned) foreign fighters, and have in the recent past been confronted with alleged threats and actual acts of terrorism within their own borders. ${ }^{8}$

4 E.g. Macklin, A. \& Bauböck, R. (eds) (2015). The Return of Banishment: Do the New Denationalisation Policies Weaken Citizenship?, EUI Working papers RSCAS 2015/14, Florence: European University Institute; Choudhury, T. (2017). The radicalisation of citizenship deprivation, Critical Social Policy $37(2)$, pp. 225-244.

5 Institute on Statelessness and Inclusion (2020). Citizenship stripping as a security measurePolicy issues and the 'effectiveness' question, World Statelessness Report 2020, pp. 227-238, at p. 228.

6 Ibid.

7 Choudhury (2017); Paulussen, C. (2018). Countering Terrorism Through the Stripping of Citizenship: Ineffective and Counterproductive, International Centre for Counter-Terrorism weblog, 17 October, available at https://icct.nl/publication/countering-terrorism-through-the -stripping-of-citizenship-ineffective-and-counterproductive/.

8 Europol (2019). EU Terrorism Situation \& Trend Report 2019 (Te-Sat), 27 June, The Hague: Europol, available at https://www.europol.europa.eu/activities-services/main-reports/ terrorism-situation-and-trend-report-2019-te-sat, p. 30, 40. 
All of them thus have a potential incentive to increase the use of citizenship deprivation.

Section two will discuss developments in the scope of citizenship deprivation legislation, and its use against individuals (allegedly) involved in terrorism in recent years. Section three discusses the immigration law consequences of citizenship revocation for the individuals concerned and especially, what the consequences are for the fight against terrorism. In the fourth section we conclude that the increased use of citizenship deprivation, especially against individuals who are outside the depriving state, is not effective as a counterterrorism approach and is likely to create more problems than it solves.

\section{Citizenship Revocation of (Alleged) Terrorists in Law and Practice}

This section discusses for each of the five countries studied the legal provisions on citizenship deprivation in connection to acts of terrorism, relevant legislative developments in recent years, and the nature and scale of citizenship deprivation. The final section provides a comparative analysis.

\subsection{Belgium}

Under Article 23 of the Code of the Belgian Nationality, only citizens who have not obtained their citizenship from a parent or through birth can have their citizenship annulled. ${ }^{9}$ Loss of citizenship must not lead to statelessness for the individual involved..$^{10}$ Until 2012, the sole grounds for citizenship loss were fraud during the acquisition of citizenship and seriously falling short of the individual's duties as a Belgian national. Terrorist offences could be seen to fall under this latter ground, if these actions resulted in a threat to Belgian security, as can be seen from sporadic executive decisions and litigation that has occurred. ${ }^{11}$ From 2012, a number of changes have broadened the grounds for citizenship deprivation in Belgium. A new Article 23/1 entered into force in December of that year, which introduced a number of new deprivation grounds, conditional on a judge's approval of a request made by the public prosecutor. These include a conviction to at least five years in prison for

9 Article 23 § 1 Code of the Belgian Nationality, available at https://www.ejustice.just.fgov .be/cgi_loi/change_lg.pl?language $=$ nl\&la $=\mathrm{N} \& \mathrm{cn}=1984062835 \&$ table_name $=$ wet.

10 Unless in cases of fraud, see Art. $23 \S 1-2^{\circ} ; 23 / 1 \S 2$ and $23 / 2 \S 2$ Code of the Belgian Nationality.

11 P. Wautelet (2016). Deprivation of citizenship for 'jihadists'. Analysis of Belgian and French practice and policy in light of the principle of equal treatment. SSRN paper, Amsterdam: Elsevier, p. 2, available at: https://papers.ssrn.com/sol3/papers.cfm?abstract_id=2713742. 
specified terrorist acts, if citizenship was obtained less than ten years before the commission of the act. ${ }^{12}$ In July 2015 Article $23 / 2$ was introduced, ${ }^{13}$ which moved the terrorist offences to a separate provision, broadened the scope of terrorist offences covered and removed the temporal limitations regarding the possession of Belgian citizenship. ${ }^{14}$ More recently, there have been attempts to further broaden the scope by removing some of the conditions set out above, but so far, they did not obtain sufficient support in parliament, the latest attempt being rejected in February 2020. ${ }^{15}$

While it was possible to revoke citizenship in relation to terrorism in Belgium already before a number of changes were implemented in the legislation from 2012 , it was used only very occasionally, as noted above. Based on a search in media reports, between 2009 and January 2020 , a total of at least 21 individuals have lost their Belgian citizenship in relation to convictions for terrorist activities, four of whom are women. Three individuals of Tunisian, and one of Moroccan descent, lost their Belgian citizenship between 2009 and 2011. ${ }^{16}$ The other 17 individuals lost their Belgian citizenship between November 2017 and January 2020 and almost all are of Moroccan descent. They include four individuals who were in Belgium at the time of revocation (the latter two serving prison sentences): 'black widow of the jihad' Malika el Aroud, Bilal Soughir of Tunisian descent, Enis Sulejmani of Serbian descent, and leader of the radical Islamist movement Sharia4Belgium Fouad Belkacem. The remaining 13 individuals are foreign fighters believed to be in Syria. ${ }^{17}$

12 Wautelet (2016).

13 'Wet tot versterking van de strijd tegen het terrorisme' of 20 July 2015, [C-2015/o9385], Belgisch Staatsblad 05.08.2015, 49326; Wetsontwerp [draft law] of 22 June 2015, doc 54 1198/oo1.

14 Beernaert, M-A. (2015). Renforcement de l'arsenal législatif anti-terroriste: entre symboles et prevention. Journal des tribunaux 134(40-6626), pp. 833-836; Wautelet (2016).

15 N-VA-voorstel over afname Belgische nationaliteit weggestemd, De Morgen, 18 February 2010, available at https://www.demorgen.be/politiek/n-va-voorstel-over-afname-bel gische-nationaliteit-weggestemd.

16 Deze vier terroristen verloren hun Belgische nationaliteit, De Standaard, 13 June 2017, available at https://www.standaard.be/cnt/dmf20170613_o2923313.

17 'Terreurimam' uit Berchem krijgt acht jaar cel en verliest de Belgische nationaliteit, $H L N$, 12 November 2018, available at https://www.hln.be/nieuws/binnenland/-terreurimam -uit-berchem-krijgt-acht-jaar-cel-en-verliest-de-belgische-nationaliteit a1fdf6d9/; Belgische rechter geeft IS-weduwen bij verstek vijf jaar cel en pakt nationaliteit af, $A D$, 19 December 2019, available at https://www.ad.nl/buitenland/belgische-rechter-geeft -is-weduwen-bij-verstek-vijf-jaar-cel-en-pakt-nationaliteit-af a3ad3384/; G. Van Vlierden, 'Zij zijn geen Belg meer: nationaliteit van zes Syriëstrijders afgepakt', $H L N, 2$ January 2020, available at https://www.hln.be/de-krant/zij-zijn-geen-belg-meer-nationaliteit-van -zes-syriestrijders-afgepakt aze2ao4c/. 


\subsection{France}

In France, the possibility to deprive a national of his or her citizenship in relation to terrorism was introduced already in 1996, in the form of Article 25 of the Code Civil. ${ }^{18}$ The provision lists a number of categories of acts and crimes that - after a conviction — could lead to citizenship deprivation, and include convictions for acts against the fundamental interests of the nation or crimes or offences constituting acts of terrorism (sub 1 and 2). ${ }^{19}$ The deprivation of citizenship may only be used against naturalized citizens and it may not lead to statelessness for the individual involved. ${ }^{20}$ The deprivation decision is taken by the Council of Ministers, after the individual has been informed by the Minister of the Interior and had a chance to respond, and after consulting the Council of State. ${ }^{21}$ Over the years, the provision underwent a number of changes. $^{22}$ In 2003 the scope of the provision was expanded to include terrorist acts committed up to ten years before naturalisation, ${ }^{23}$ while in 2006 the temporal scope of Art. 25 Civil Code was expanded to cover crimes committed 15 years before and after the day of naturalisation. ${ }^{24}$

The most recent attempts to change the provision occurred following the November 2015 Paris attacks. Whereas Francois Hollande's government had previously opposed two bills extending deprivation powers to citizens who obtained French nationality by birth, now the President himself called for a change of the constitution that would extend deprivation powers to French-born citizens, as long as they also held a second nationality. The bill that was proposed in early 2016 was rejected, something that was seen as a major blow to the Hollande government. According to Fargues, the core issue in the debate was that the bill would lay down in the constitution the discrimination between French dual and mono-nationals; there was not enough support to extend citizenship deprivation beyond the group of naturalized citizens. ${ }^{25}$

18 Wautelet (2016).

19 Art. 25 Code Civil, available (in French) at https://www.legifrance.gouv.fr/affichCode .do?cidTexte=LEGITEXTooooo6o70721. According to Mantu (2018: 35), other grounds are "(3) conviction for crimes considered to be crimes against the public administration (crimes committed by persons holding a public office); (4) acts of insubordination; and (5) engaging, for the benefit of a foreign state, in acts that are incompatible with the quality of French national and commission of acts that are prejudicial to the interests of France".

20 Art. 25 Code Civil reads: "L'individu qui a acquis la qualité de français ...", and “... sauf si la déchéance a pour résultat de le rendre apatride" (emphasis added).

21 Wautelet (2016).

22 Wautelet (2016); Fargues (2017).

23 Wautelet (2016).

24 Fargues (2017).

25 Ibid. 
The Ministry of the Interior reported in 2016 that since 1996, 13 dual nationals had lost their French nationality in relation to convictions for terrorist crimes. ${ }^{26}$ Between 2016 and January 2020, a further three nationals reportedly lost their French nationality for terrorist crimes. ${ }^{27}$ Of these in total 16 cases from 1996 to 2020, six individuals used to hold the Algerian nationality besides the French nationality, another seven the Moroccan nationality, one the Tunisian, one the Turkish, and there was one case we could not find in media reporting. Different from Belgium, it seems France has in recent years rarely revoked the citizenship of dual nationals believed to be in Syria or Iraq.

\subsection{Germany}

Similar to Belgium and France, only dual nationals can lose their German citizenship. ${ }^{28}$ Until recently, however, loss of German citizenship was possible only when a dual national joined the armed forces of a foreign state whose citizenship he possessed, under Article 28 of the German Nationality Act, while a naturalization decision that resulted from fraud could be revoked under Article $35 ;^{29}$ Article 28 was not applicable to members of non-state armed groups like IS. ${ }^{30}$ In June 2019, the German parliament adopted a revised version of Article 28 Nationality Act that entered into force on 9 August 2019. ${ }^{31}$ The

26 Qui sont les derniers déchus de la nationalité française?, Le Parisien, 6 January 2016, available online at http://www.leparisien.fr/archives/qui-sont-les-derniers-dechus-de-la -nationalite-francaise-o6-01-2016-5426243.php.

27 Sideris, F. (2019). Déchéance de nationalité: une seizième personne depuis 2016 perd sa citoyenneté, La Chaîne Info, 26 October 2019, available online at https://www.lci.fr/ terrorisme/decheance-de-nationalite-une-seizieme-personne-perd-sa-citoyennete-2135912 .html.

28 Section 16 Basic Law (Grundgesetz; translation available at https://www.gesetze-im -internet.de/englisch_gg/englisch_gg.html\#poog2); K. Roithmaier (2019). Germany and its Returning Foreign Terrorist Fighters: New Loss of Citizenship Law and the Broader German Repatriation Landscape, 18 April, The Hague: ICCT, available at https://icct.nl/publication/ germany-and-its-returning-foreign-terrorist-fighters-new-loss-of-citizenship-law-and -the-broader-german-repatriation-landscape/.

29 See an official English translation of the old version of the Nationality Act, available at https://wellington.diplo.de/blob/2138368/4aefbfa3bb3ba4565756275b29723a37/staatsan gehoerigkeitsgesetz-englisch-data.pdf.

30 See Wissenschaftlicher Dienst des Bundestages (2016). Verlust der Staatsangehörigkeit bei IS-Kämpfern - Rechtslage in ausgewählten EU-Staaten. Sachstand WD3-30oo-270/16, Berlin: Bundestag, p. 4, available at: https://www.bundestag.de/blob/493610/4aefge281154 co735ecd5dad5d5805ac/wd-3-270-16-pdf-data.pdf.

31 Bundesregierung (2019). Deutscher Pass kann aberkannt werden, Berlin: Bundesregierung, official website of the Bundesregierung [the Federal Government], 9 August 2019, available at https://www.bundesregierung.de/breg-de/service/gesetzesvorhaben/deutscher -pass-kann-aberkannt-werden-1596980. 
newly introduced provision requires that the individual in question has "concretely participated in combat operations by a terrorist organization abroad". Notably, a criminal conviction for a terrorist offense is not required. ${ }^{32}$ The clause may not be applied retroactively, and the provision can therefore not be applied to individuals who travelled abroad to join IS before August 2019. ${ }^{33}$ The decision to revoke is made by a state agency, not by a court. ${ }^{34}$

Since it was adopted recently and cannot be applied retroactively, the new provision of the Nationality Act has not been applied in practice at the moment of writing. According to the Federal Criminal Police Office (Bundeskriminalamt) of Germany, around 1.050 individuals have travelled from Germany to Iraq and Syria to join IS. ${ }^{35}$ According to the Ministry of the Interior, a "low three-digit number" of them are dual nationals. ${ }^{36}$ It is particularly these individuals who may be affected by citizenship revocation albeit only for 'concrete participation in hostilities by a terrorist organization' after that law was enacted.

\section{$2.4 \quad$ The Netherlands}

Citizenship deprivation in the Netherlands is based on Article 14 of the Nationality Act. ${ }^{37}$ The decision is taken by the Minister of Justice and Security (or on his behalf by the executive). Deprivation may not result in statelessness (Art. 14(8)), so it can only apply to dual citizens. Before 2010, citizenship could be revoked only if nationality was obtained based on fraud or concealment of relevant facts, whereas voluntary military service in a foreign (state) armed force could lead to "loss" of citizenship. ${ }^{38}$ This provision was never used in relation to terrorist activity. Since 2010, three changes to the Nationality Act have

32 Section 28(1) Nationality Act reads: “... sich an Kampfhandlung einer terroristischen Vereinigung im Ausland konkret beteiligt”. Sections 129 and 129a Criminal Code [Strafgesetzbuch] define the concept of terrorist organizations.

33 Bundesregierung (2019). Deutscher Pass kann aberkannt werden, Berlin: Bundesregierung.

34 Section 28(3) Nationality Act.

35 BKA: Rund ein Drittel der 105 o deutschen IS-Kämpfer wieder zurück in Deutschland, Die Zeit, 14 February 2019, available at https://www.zeit.de/news/2019-02/14/bka-rund-ein -drittel-der-1050-deutschen-is-kaempfer-wieder-zurueck-in-deutschland-20190214 -doc-1df6tp.

$36 \quad 5^{1}$ deutsche IS-Kämpfer in Händen kurdischer Kräfte, Der Tagesspiegel, 7 March 2019, available at https://www.tagesspiegel.de/politik/syrien-51-deutsche-is-kaempfer-in-haen den-kurdischer-kraefte/24079152.html.

37 Rijkswet op het Nederlanderschap, available (in Dutch) at https://wetten.overheid.nl/ BWBRooo3738/2018-o8-o1\#Hoofdstuk5_Artikel14.

38 On the basis of Art. 14(1) and 15(1)(e); see a previous version of the Nationality Act at https://wetten.overheid.nl/BWBRooo3738/2009-o3-o1. 
been implemented that have broadened the scope of the deprivation powers in this respect.

In October 2010, a new subsection 14(2) introduced a basis for revocation when a person has been irrevocably convicted because of certain crimes in relation to state security and international relations punishable by an 8-year prison sentence or more, as well as the specifc crimes of terrorism or recruitment for an armed struggle or for an alien armed force. ${ }^{39}$ In March 2016, the scope of terrorist crimes covered was expanded to preparatory acts for terrorist crimes. ${ }^{40}$ In March 2017, a new subsection 14(4) made it possible to revoke the nationality without a conviction, "in the interest of national security" of a person who has reached the age of 16 and who is outside the Kingdom, if his conduct shows that he has joined an organization that has been placed on a list of organizations that partake in a national or international armed conflict and poses a threat to national security. ${ }^{41}$

In September 2017, a couple of months after it was introduced, the new competence to revoke the Dutch nationality on national security grounds was used for the first time, against four Dutch-Moroccan individuals. ${ }^{42}$ Since then, there were five more revocations in $2018,{ }^{43}$ ten revocations in $2019,{ }^{44}$ and (so far) four in $2020 .{ }^{45} \mathrm{Of}$ these 23 cases in total, however, seven deprivation decisions were reversed in 2019 because they had been based on retroactive application. ${ }^{46}$ Of the 16 remaining cases, 12 individuals were born in the Netherlands, four abroad. Most of the individuals are of Moroccan descent, but there are also individuals of Egyptian, Iraqi and Turkish descent; two of them are women. 14 cases are based on art. 14(4) Nationality Act, which means the individuals

39 Staatsblad [official journal] 2010, 242, available at https://zoek.officielebekendmakingen .nl/stb-2010-242.html (translation by authors).

40 Staatsblad 2016, 121, available at https://zoek.officielebekendmakingen.nl/stb-2016-121 .html (translation by authors.

41 Staatsblad 2017, 52, available at https://zoek.officielebekendmakingen.nl/stb-2017-52 .html (translation by authors). The list is available at https://zoek.officielebekendmakingen.nl/stcrt-2017-13023.html.

42 Staatscourant, 2017, 52440, 13 September.

43 Staatscourant, 2018, 39597, 11 July; 63407, 7 November.

44 Staatscourant, 2019, 3532, 21 January; 11642, 27 February; 22177, 17 April; 27574, 10 May; 50454, 6 September; 6o3o9, 3о October; 67223, 3 December; 67227, 3 December; 69330, 12 December.

Staatscourant, 2020, 4746, 20 January; 5678, 23 January; 6215, 27 January; 25604, 4 May.

46 See Council of State, judgment of 17 April 2019, ECLI:NL:Rvs:2019:99o, available at https://www.raadvanstate.nl/@114910/201806107-1-v6/; judgment of 17 April 2019, ECLI:NL:RVS:2019:1246, available at https://www.raadvanstate.nl/@114911/201806104 -1-v6/; and Staatscourant 2019, 52809, 23 September. 
are (presumably) abroad; only one case is based on a conviction for a terrorist crime and art. 14(2) Nationality Act. ${ }^{47}$

\subsection{United Kingdom}

Deprivation of citizenship in the UK is currently regulated in Sections 40, 40A and $40 \mathrm{~B}$ of the British Nationality Act $1981 .{ }^{48}$ On the basis of section $40(2)$ British Nationality Act, the Secretary of State may order the deprivation of citizenship if he "is satisfied that deprivation is conducive to the public good". The UK government considers deprivation conducive to the public good when the individual has been involved in activities involving certain serious crimes, as well as acts of terrorism and "unacceptable behaviour" such as glorification of terrorism..$^{49}$ The Secretary of State has considerable discretionary room to use the deprivation power based on this ground, as its use is not contingent on a criminal conviction for a terrorist offence, nor on any other kind of judicial approval..$^{50}$

The current provisions result from a number of changes since 2003, which have significantly broadened the scope and applicability of the deprivation powers. First, an amendment implemented in 2003 introduced a general power, instead of more specific grounds, to deprive a British citizen of citizenship who had done "anything seriously prejudicial to the vital interest of the United Kingdom or a British overseas territory", and expanded its reach to citizenship acquired by birth; however, it also introduced protection against statelessness. ${ }^{51}$ Second, in the aftermath of the 2005 London bombings, the "seriously prejudicial" standard was replaced by the much lower standard that deprivation was to be "conducive to the public good".52 Third, in July 2014, Section $40(4 \mathrm{~A})$ introduced a unique exception to the protection against statelessness: rendering a naturalized citizen stateless is acceptable when he or she "conducted him or herself in a manner which is seriously prejudicial to the vital interests of the United Kingdom, any of the Islands, or any British

47 Staatscourant, 2019, 22177, 17 April.

48 British Nationality Act 1981, available at http://www.legislation.gov.uk/ukpga/1981/61.

49 E.g. UK Home Office, HM Government Transparency Report 2018: Disruptive and Investigatory Powers, London: Home Office, p. 26.

50 Anderson, D., Q.C. (2016). Citizenship Removal Resulting in Statelessness. Independent Reviewer of Terrorism Legislation, April, at 2.9; available at https://assets.publishing .service.gov.uk/government/uploads/system/uploads/attachment_data/file/518120/David _Anderson_QC_-_CITIZENSHIP_REMOVAL_web_.pdf, at 3.16-3.18.

51 Gibney, M.J. (2013). 'A Very Transcendental Power': Denaturalisation and the Liberalisation of Citizenship in the United Kingdom, Political Studies 61, pp. 637-655; Anderson (2016), at 2.9.

$5^{2}$ Gibney (2013: 650); Anderson (2016), at 2.14. 
overseas territory" and if the Secretary of State has "reasonable grounds for believing that the person is able, under the law of a country or territory outside the United Kingdom, to become a national of such a country or territory". ${ }^{3}$

Before the citizenship deprivation powers were broadened from 2003 onwards, these powers were used only occasionally. ${ }^{54}$ From then, the numbers started to rise slowly. Gibney reports that the early case in 2003 of Abu Hamza, who successfully appealed his deprivation but was later extradited to and convicted in the US, ${ }^{55}$ was followed by thirteen deprivation decisions between January 2006 and May 2011, "almost all because of suspected links with Islamist terrorism". ${ }^{56}$ The Home Office's Transparency Reports on Disruptive and Investigatory Powers provide numbers of deprivations on the 'conducive' ground over the period 2010-2018: 24 between May 2010 and the end of December 2013; four in 2014; $;^{57}$ five in $2015 ;{ }^{58} 14$ in 2016; 104 in 2017; 59 and 21 in $2018 .{ }^{60}$ The numbers for 2019 and 2020 are not available yet. It is important to note that these are not necessarily terrorism cases, as the Transparency Reports point out the UK government also sees war crimes and other serious crimes to fall under Section $40(2)$.

Information from the 'Bureau of Investigative Journalism', which has tracked citizenship revocations in the UK between 2002 and 2016, in combination with other public information reveals some background information about these cases. Considering the very considerable numbers of citizenship deprivations since 2016 , however, the picture is very incomplete. The measure

53 Section $40(4 \mathrm{~A})$ British Nationality Act.

54 Gibney (2013: 646); Anderson (2016), at 2.8.

55 Abu Hamza: Home Secretary Theresa May hails guilty verdict, $B B C, 20$ May 2014, available at https://www.bbc.com/news/world-us-canada-27478998.

$56 \quad$ Ibid.

57 UK Home Office (2015). HM Government Transparency Report 2015 (November), London: Home Office, available at https://assets.publishing.service.gov.uk/government/uploads/ system/uploads/attachment_data/file/4736o3/51973_Cm_9151_Transparency_Accessible .pdf.

58 UK Home Office (2017). HM Government Transparency Report 2017 (February), London: Home Office, available at https://assets.publishing.service.gov.uk/government/uploads/ system/uploads/attachment_data/file/593668/58597_Cm_942O_Transparency_report _web.pdf.

59 UK Home Office (2018). HM Government Transparency Report 2018 (July), London: Home Office, available at https://assets.publishing.service.gov.uk/government/uploads/ system/uploads/attachment_data/file/727961/CCS207_CCSo418538240-1_Transparency _Report_2018_Web_Accessible.pdf.

6o UK Home Office (2020). HM Government Transparency Report: Disruptive Powers 2018/ 19 (March), London: Home Office, available at https://www.gov.uk/government/pub lications/transparency-report-disruptive-powers-2018-to-2019. 
touches individuals who hold (or are believed to be able to obtain) a wide variety of nationalities, including Afghan, Australian, Bangladeshi, Canadian, Iraqi, Lebanese, Moroccan, Nigerian, Pakistani, Somali, Sudanese, Syrian, Turkish and Vietnamese.

\subsection{Comparative Analysis}

All of the five countries studied above have recently implemented changes to existing nationality legislation that have created or broadened possibilities for citizenship deprivation in relation to terrorist offences or national security. As depicted in Table 1, however, the grounds and conditions are highly diverse. A number of differences stand out. In Germany, citizenship deprivation in relation to terrorist activity has only been possible since August 2019 and only nonretroactively, which explains why there have been no cases so far. The scope of the German provision on deprivation in relation to terrorism is relatively narrow as deprivation has to be based on evidence that the individual has participated in combat operations by a terrorist organization abroad; this means it cannot target terrorist acts unrelated to combat operations or that occur domestically. In Belgium and France, deprivation (or loss) of citizenship has already been possible for over ten years and can be imposed as an additional measure following a conviction for terrorist crimes (in Belgium to at least a five-year-prison sentence). In the Netherlands and the UK, however, citizenship deprivation in relation to terrorist acts is not necessarily (and in practice almost never) connected to a criminal conviction. In the Netherlands, most deprivation decisions concern individuals outside the country and are made 'in the interest of national security'. As discussed above, the reach of the citizenship deprivation provisions is the broadest in the UK.

When looking at the number of citizenship deprivations, as summarised in Table 2, it is notable that Germany (which is not included as it has no cases) and UK are the two extremes. The UK has had a limited but stable number of deprivations for a longer period of time, but this exploded in 2017, although the number of deprivation decisions 'conducive to the public good' in the following year was considerably lower. Overall, the total number of cases in the UK is much higher than in the other countries. The total numbers of cases in Belgium, France and the Netherlands are comparable, but when looking at developments over time, it seems that France is lagging behind recently. While in Belgium and Netherlands numbers have substantially increased in the last three years, we do not (yet) see this in France. This, together with the rejection of further expansion of deprivation powers in 2016, may signal that there is recently more hesitance in France to use this measure-although it may be too early to draw conclusions, because there may be a delay in deprivations 
TABLE 1 Grounds and conditions for citizenship deprivation for acts linked to terrorism in the countries studied $^{\mathrm{a}}$

\begin{tabular}{|c|c|c|c|c|c|}
\hline & Belgium & France & Germany & Netherlands & United Kingdom \\
\hline $\begin{array}{l}\text { Relevant } \\
\text { legal } \\
\text { provisions }\end{array}$ & $\begin{array}{l}\text { Art. } 23,23 / 2 \text { Code } \\
\text { of the Belgian } \\
\text { Nationality }\end{array}$ & Art. 25 Civil Code & $\begin{array}{l}\text { Art. } 28 \\
\text { Nationality } \\
\text { Act }\end{array}$ & $\begin{array}{l}\text { Art. } 14 \\
\text { Nationality Act }\end{array}$ & $\begin{array}{l}\text { Section } 40 \text { British } \\
\text { Nationality Act } \\
1981\end{array}$ \\
\hline $\begin{array}{l}\text { Relevant } \\
\text { grounds }\end{array}$ & $\begin{array}{l}\text { Falling short of a } \\
\text { Belgian national's } \\
\text { duties }(23) ; \\
\text { conviction to a } \\
\text { prison sentence of } \\
\text { at least five years } \\
\text { for listed terrorist } \\
\text { offences }(23 / 2)\end{array}$ & $\begin{array}{l}\text { Conviction for } \\
\text { acts against the } \\
\text { fundamental } \\
\text { interests of the } \\
\text { nation }(25(1)) \text {; } \\
\text { crimes or offences } \\
\text { constituting acts of } \\
\text { terrorism }(25(2))\end{array}$ & $\begin{array}{l}\text { Evidence } \\
\text { of concrete } \\
\text { participation } \\
\text { in hostilities } \\
\text { by a terrorist } \\
\text { organization } \\
\text { abroad }\end{array}$ & $\begin{array}{l}\text { Conviction for } \\
\text { listed terrorist } \\
\text { acts }(14(2)) \text {; 'in } \\
\text { the interest of } \\
\text { national security' } \\
\text { if joined listed } \\
\text { organization } \\
\text { abroad }(14(4))\end{array}$ & $\begin{array}{l}\text { Secretary of } \\
\text { State is satisfied } \\
\text { that deprivation } \\
\text { is conducive to } \\
\text { the public good } \\
(40(2))\end{array}$ \\
\hline $\begin{array}{l}\text { Key } \\
\text { moments in } \\
\text { expansion of } \\
\text { deprivation } \\
\text { powers in } \\
\text { relation to } \\
\text { terrorism }\end{array}$ & $\begin{array}{l}\text { 1984: Introduction } \\
\text { 2012: Expansion } \\
\text { of terrorist acts } \\
\text { listed } \\
\text { 2015: Further } \\
\text { expansion of } \\
\text { terrorist acts listed }\end{array}$ & $\begin{array}{l}\text { 1996: Introduction } \\
\text { 2003: Extension of } \\
\text { time limits between } \\
\text { commission of } \\
\text { crime and moment } \\
\text { of naturalisation } \\
\text { 2006: Further } \\
\text { extension of time } \\
\text { limits }\end{array}$ & $\begin{array}{l}\text { 2019: } \\
\text { Introduction }\end{array}$ & $\begin{array}{l}2010 \text { : } \\
\text { Introduction } \\
2016 \text { : Expansion } \\
\text { of terrorist acts } \\
\text { listed } \\
2017 \text { : 'In } \\
\text { the interest } \\
\text { of national } \\
\text { security' ground }\end{array}$ & $\begin{array}{l}\text { 2003: 'Seriously } \\
\text { prejudicial' } \\
\text { standard } \\
2006 \text { : 'Conducive } \\
\text { to the public good' } \\
\text { standard } \\
\text { 2014: Exception in } \\
\text { protection against } \\
\text { statelessness }\end{array}$ \\
\hline $\begin{array}{l}\text { Criminal } \\
\text { conviction } \\
\text { required? }\end{array}$ & $\begin{array}{l}\text { Yes, to at least five } \\
\text { years in prison }\end{array}$ & Yes & No & $\begin{array}{l}\text { Not if based on } \\
\text { art. } 14(4)\end{array}$ & No \\
\hline $\begin{array}{l}\text { Who takes } \\
\text { the decision }\end{array}$ & $\begin{array}{l}\text { Art. 23: Court } \\
\text { of Appeal on } \\
\text { request of public } \\
\text { prosecutor; art. } \\
23 / 1 \text { and Art. } 23 / 2 \text { : } \\
\text { civil or criminal } \\
\text { court on request of } \\
\text { public prosecutor }\end{array}$ & $\begin{array}{l}\text { Council of } \\
\text { Ministers, after } \\
\text { consulting Council } \\
\text { of State }\end{array}$ & $\begin{array}{l}\text { Regional } \\
\text { or national } \\
\text { state } \\
\text { authority }\end{array}$ & $\begin{array}{l}\text { Minister of } \\
\text { Justice and } \\
\text { Security }\end{array}$ & Secretary of State \\
\hline $\begin{array}{l}\text { Only natural- } \\
\text { ized citizens? }\end{array}$ & Yes & Yes & No & No & No \\
\hline $\begin{array}{l}\text { Can the per- } \\
\text { son become } \\
\text { stateless after } \\
\text { deprivation? }\end{array}$ & No & No & No & No & $\begin{array}{l}\text { Naturalized } \\
\text { citizens: Yes, if } \\
\text { believed to be } \\
\text { able to acquire } \\
\text { another state's } \\
\text { citizenship; } \\
\text { natural-born } \\
\text { citizens: No }\end{array}$ \\
\hline
\end{tabular}

a In the UK, before 2003, deprivation was also hypothetically possible in relation to terrorism, but did not occur in practice. 
TABLE 2 Number of citizenship deprivations for acts linked to terrorism in the countries studied $^{\mathrm{a}}$

\begin{tabular}{lcccc}
\hline & Belgium & France & Netherlands & United Kingdom \\
\hline$<2014$ & 2 & 7 & - & $24+$ \\
2014 & - & 1 & - & 4 \\
2015 & - & 5 & - & 5 \\
2016 & - & - & - & 14 \\
2017 & 4 & - & 1 & 104 \\
2018 & 6 & - & 2 & 21 \\
2019 & 3 & 3 & 9 & $?$ \\
2020 & 6 & - & 4 & $172+$ \\
Total & 21 & 16 & 16 & $?$ \\
\hline
\end{tabular}

a It has to be noted that this information is drawn from public sources and may therefore be incomplete or inaccurate. Decisions may not be definitive, or may have been reversed without this being reported in public sources. It is also possible that there are cases which have not (yet) been reported or are otherwise known to the public.

because decisions are still under appeal, or because criminal convictions have not yet materialised (which is a condition for citizenship deprivation in France, as in Belgium). to Terrorism

A decision to deprive someone of citizenship has far-reaching direct and indirect consequences for the individual concerned. This section discusses the direct immigration law consequences for the individuals deprived of citizenship: how deprivation impacts their residence status, what measures are taken towards removal or preventing entry, and what follow-up scenarios may occur. It is important to note that someone who loses citizenship does not necessarily also lose legal residence; in practice, however, citizenship deprivation will often be followed by a decision or act declaring someone's stay illegal and stating an obligation to 'return' to a country of origin, (residual) nationality or habitual residence (a 'return decision' in EU law), and/or a measure preventing legal entry, such as an entry ban. ${ }^{61}$ Indirect consequences can take many

61 Art. 3(4) and (6) of Council Directive 2008/115/EC (Return Directive). 
forms; if the ties with a country where someone may have lived all his life are severed, this has serious consequences in all domains of the individual's personal life, in more and less tangible ways: from access to their family, social or professional life, to their identity and sense of belonging.

What consequences a deprivation decision has-and to what extent this decision benefits domestic national security - to a large extent depends on where the individual is at the time of the deprivation: inside the depriving state, or (presumably) outside the depriving state. ${ }^{62}$ In principle, there are always two, and possibly three or more state parties in the equation: the depriving state, the state of residual nationality, and possibly one or more third states. How citizenship deprivation can theoretically play out is outlined in Figure 1 below. Sections 3.1 and 3.2 describe the different scenarios more extensively, illustrated with concrete examples of cases that have occurred in the five countries studied. Possible outcomes are independent departure, extradition, expulsion, or 'legal limbo': the latter being a situation where someone for a considerable period of time is unremovable from the host state, without a defined immigration status and attendant access to basic rights. ${ }^{63}$

\subsection{Deprivation in the Depriving State}

If the individual is on the territory of the depriving country at the time of the deprivation decision, and the decision becomes final, he will typically also lose legal residence and be ordered to leave. ${ }^{64}$ The state can enforce this through different modalities: by encouraging independent departure (voluntary return), by means of facilitating extradition for the purpose of criminal prosecution elsewhere, or by pursuing forced return in the form of expulsion (possibly with diplomatic assurances).

Independent departure - whereby the individual after deprivation 'voluntarily' and/or independently returns to the state of residual nationality or a third state willing to receive him-is an ideal scenario from the depriving state's perspective. In practice, it is unlikely that someone will just accept such a far-reaching decision and leave to another state. On the other hand, it is not

62 If a foreign fighter's last known whereabouts are Iraq or Syria, but no recent or reliable information is available, authorities in the depriving state will typically assume the individual is abroad.

63 See the special issue on "Undesirable and Unreturnable" Aliens in Asylum and Immigration Law (Oxford University Press 2017), Refugee Survey Quarterly, 36(1).

64 In the Netherlands, for instance, revocation decisions are often accompanied by persona non grata declarations (based on art. 67 Dutch Aliens Act 2000), rendering expatriated individuals illegal aliens. Furthermore, that expatriated individuals typically lose legal residence can be inferred from the examples of attempts to deport them that we will discuss. 

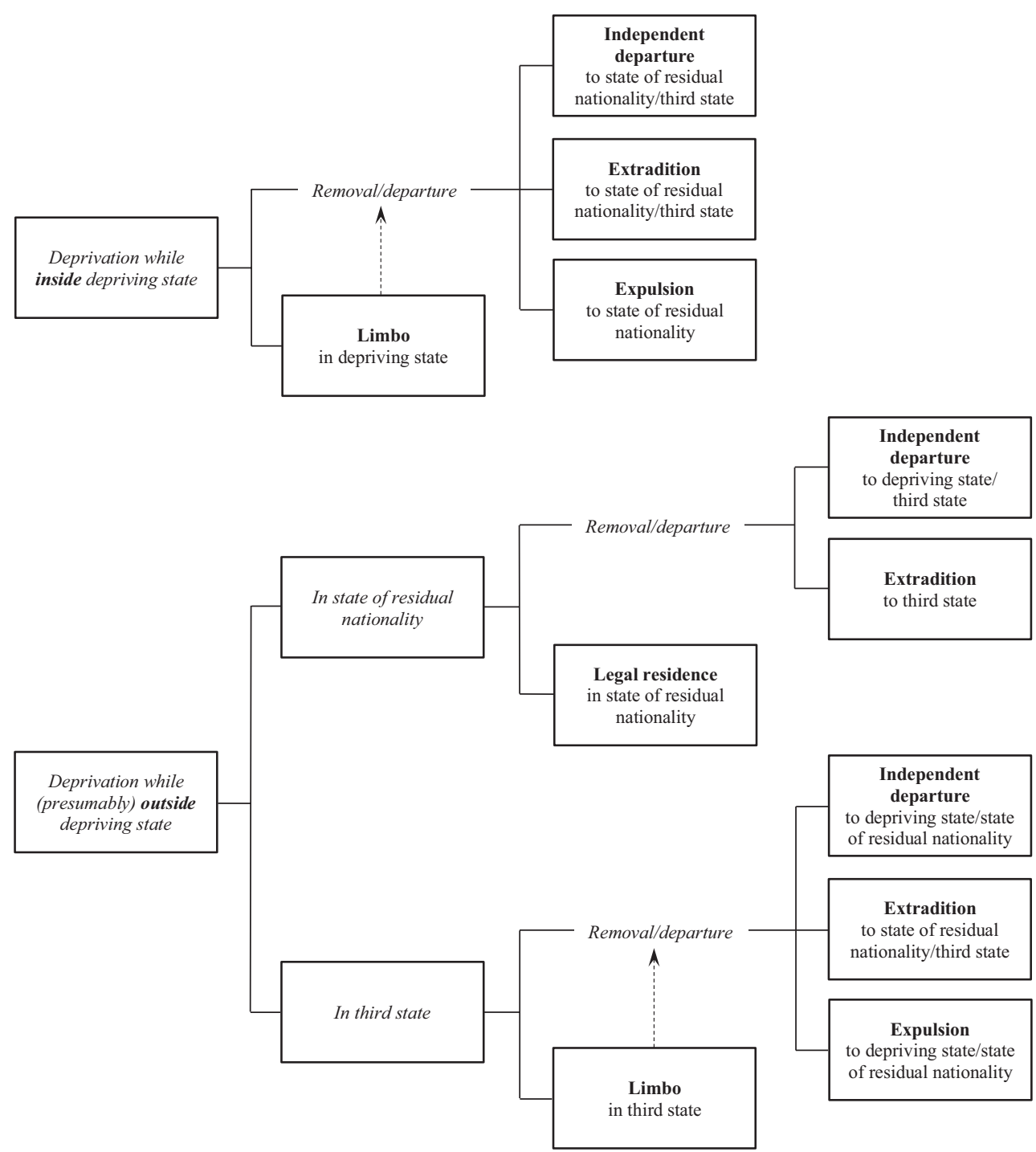

FIGURE 1 Overview of follow-up scenarios to citizenship deprivation for acts linked to terrorism

Note: i) Obstacles blocking expulsion or extradition (such as concerns regarding the human rights situation in, or cooperation from the receiving state) may be temporary, and therefore, so is a situation of limbo; the dotted arrows show possible follow-ups to limbo. Despite their temporary nature, in practice limbo situations often last for many years.

ii) Our assumption is that 'legal residence in the depriving state' is not a possibility, because it is unlikely that an expatriated individual has or will be given legal residence; from the moment he loses legal residence, he is in limbo.

iii) The removal and departure options are not necessarily final outcomes. They can be followed by legal residence or limbo, but also by subsequent expulsion or extradition. 
impossible that someone chooses to 'cut his losses' and leaves through the 'back door', especially if an environment is created that makes it very unattractive to stay. It is difficult to refer to examples of this option, because such cases are unlikely to draw public attention. In particular from a global counterterrorism perspective, this scenario is not ideal as this may cause (alleged) terrorists to disappear from the radar.

Extradition is in principle only possible if three conditions are met. First, it has to be requested by a state that wants to prosecute the person, substantiated with evidence. Second, it is only possible if prosecution relates to conduct for which the individual has not already been prosecuted (otherwise extradition would violate the right not to be tried or punished twice under Article 4 of Protocol no. 7 to the ECHR). Third, extradition should not violate the individual's rights, e.g. based on Article 3 (non-refoulement) or 6 (fair trial) ECHR. Since citizenship deprivation may follow on a criminal conviction in the depriving state, or a new criminal trial may violate Articles 3 or 6 ECHR, it can be expected that expatriated individuals will challenge their extradition in court. Extradition could be seen, however, to (temporarily) neutralise a security threat.

The threshold for expulsion appears to be lower compared to extradition, as it does not require another state to make a request. However, deportation can also be expected to lead to extensive legal and political wrangling, as we will show below. In this respect, a revocation decision is not a 'quick win' in terms of counter terrorism policies; depriving states can expect long and tedious procedures to actually effectuate forced removal. In our analysis of case law we have come across various illustrations in this regard.

Expulsion may be (temporarily) prevented from being executed pending the outcome of a legal challenge of the deprivation itself, or if it would violate the individual's human rights, causing the individual to end up in legal limbo. This can be because the individual argues the act of deprivation violates his rights. For instance, in a pending case at the ECtHR, the expulsion of four individuals of Moroccan and one of Turkish descent has been suspended because they challenged the deprivation of their nationality as an infringement of their right to identity, based on Article 8 (right to respect for family and private life) of the European Convention on Human Rights (ECHR), and as a "disguised penalty" for conduct for which they have already served a sentence, based on Article 4 of Protocol no. 7 to the ECHR. ${ }^{65}$ Expulsion can also be suspended

65 ECtHR, Ghoumid and 4 others v. France, application no. 52273/16, communicated on 23 May 2017, available at https://hudoc.echr.coe.int/eng\#\{\%22itemid\%22:[\%22001-1744 79\%22]\}; ECtHR (2020). Factsheet Deprivation of citizenship, Strasbourg: Council of 
if there is a risk that the act of expulsion violates the individual's rights. In Daoudiv. France, the court concluded that deportation to Algeria would violate Article 3 ECHR (non-refoulement), ${ }^{66}$ as it was likely that Daoudi would be targeted by the Algerian Department for Information and Security and could be arrested, detained and subjected to ill-treatment, including torture. ${ }^{67}$ Another case where deportation was suspended due to pending appeal procedures concerns the 'black widow of the jihad' Malika el Aroud of Moroccan descent, and Bilal Soughir of Tunisian descent, who were both convicted in Belgium for acts related to terrorism in 2010 and 2008 respectively, and whose Belgian nationality was revoked on 30 November 2017. They claimed their deportation would violate Article $8 \mathrm{ECHR}$, as well as Article 2 of Protocol no. 7 to the ECHR (denial of the right to appeal). ${ }^{68} \mathrm{El}$ Aroud had earlier fought here deportation based on Articles 3 and $8 \mathrm{ECHR}$, but in February 2019, the Belgian Council for Alien Law Litigation decided that she could be expelled. ${ }^{69}$ At the time of writing there were no public records that she has actually been expelled since.

Apart from the above mentioned legal procedures, expulsion may also be suspended or fail due to 'practical' obstacles (which may encompass legal aspects), such as lack of willingness from the state of residual nationality to accept the person back or provide the necessary travel documents. In an article in the French newspaper L'Express, observers note that countries of residual nationality may take different strategies in this regard: Algeria and Morocco are generally willing to accept individuals back who are sought for prosecution or when the presence of the individuals on their soil can 'contribute' to the fight against terrorism, whereas Tunisia, for instance, is hesitant to accept

Europe, available at https://www.echr.coe.int/Documents/FS_Citizenship_Deprivation _ENG.pdf. On Art. 8 and citizenship deprivation, see e.g. ECtHR, Ramadan v. Malta, application no. 76136/12, 21 June 2016, and K2 v. the United Kingdom, 7 February 2017, application no. 42387/13, under 49-51; see also Reyntjens (2019).

66 The prohibition of refoulement is absolute-see ECtHR, Saadiv. Italy, 28 February 2008, application no. 37201/o6.

67 ECtHR, Daoudiv. France, 3 December 2009, application no. 19576/o8. See also X. v. Sweden, judgment of 9 January 2018, application no. 36417/16 (expulsion to Morocco). In A.M. v. France (29 July 2019, application no. 12148/18) the ECtHR concluded, however, that expulsion to Algeria would not violate Article 3 .

68 ECtHR, El Aroud v. Belgium, application no. 25491/18, and Soughir v. Belgium, application no. 27629/18, communicated on 8 November 2015. See also ECtHR Press unit, Press country profile on Belgium, version updated January 2020, available at https://www.echr.coe .int/Documents/CP_Belgium_ENG.pdf.

69 Belga, 'Zwarte weduwe van de jihad' Malika El Aroud mag naar Marokko worden uitgewezen, Nieuwsblad, 22 February 2019, available at https://www.nieuwsblad.be/cnt/ dmf20190222_04197996. 
back Tunisian jihadists. ${ }^{70}$ However, too much eagerness to accept back nationals may also prevent deportation. Deportation to Algeria and Morocco has for example repeatedly been ruled to violate Article 3 ECHR. ${ }^{71}$ Governments that seek to expel an expatriated individual may try to obtain diplomatic assurances or enter into memoranda of understanding (MOUs) to address possible violations. ${ }^{72}$ Another example where lack of cooperation from the country of residual nationality prevented expulsion is the case of Minh Quang Pham, whose expulsion from the UK was blocked as the Vietnamese government did not recognize his Vietnamese citizenship. ${ }^{73}$ Other practical circumstances that may be an obstacle to removal are for instance health reasons.

What happens to individuals like Kamel Daoudi, Bashir Ghoumid and Malika el Aroud, who have lost their nationality and legal residence, but can for a considerable period of time not be deported? All five countries studied have different measures in place to deal with such legal limbo-situations and it goes beyond the scope of this paper to elaborate on all these differences. It suffices that governments generally continue to monitor the whereabouts of the individuals concerned and may restrict their movement. Individuals typically lose their right to work, may be temporarily placed in immigration detention, and their access to insurances or social welfare may be blocked. The abovementioned Kamel Daoudi has been in a limbo situation in France for the past thirteen years; he has been put under the measure of 'assigned residence' and has to live away from his family and report to the police several times a day. ${ }^{74}$

70 Goupil, M. (2019). Déchéance de nationalité des binationaux: une source de tensions diplomatiques?, L'Express, 25 October 2019, available at https://www.lexpress.fr/ actualite/monde/decheance-de-nationalite-des-binationaux-une-source-de-tensions -diplomatiques_2105005.html.

71 Apart from the cases El Aroud (Morocco), Daoudi and Arous (below), see e.g. SIAC, BB and others v. SSHD, 18 April 2016.

72 See Giuffré, M. (2017). Deportation with Assurances and Human Rights. The Case of Persons Suspected or Convicted of Serious Crimes, Journal of International Criminal Justice $15(1)$, pp. $75^{-95}$.

73 UK Supreme Court, Pham v Secretary of State for the Home Department, [2015] UKSC 19, 25 March 2015, available at https://www.supremecourt.uk/cases/docs/uksc-2013 -o15o-judgment.pdf. Instead, in February 2015 the man was extradited to the US, where he was convicted to 40 years imprisonment for his support to Al Qaida in the Arab Peninsula. UK citizen Minh Quang Pham jailed for Heathrow suicide plot, $B B C, 27$ May 2016, available at https://www.bbc.com/news/uk-36403825.

74 Amnesty International (2018). Punished without trial. The use of administrative control measures in the context of counter-terrorism in France, London: Amnesty International, available online at https://www.amnesty.nl/content/uploads/2018/11/Punished-without -trial-The-use-of-administrative-control-measures-in-the-context-of-counter-terrorism -in-France.pdf?x58099. 
He also has been imposed with a duty to request other countries (that do not have an agreement with Algeria to expel him) to accept him; over 40 countries turned down his request. ${ }^{75}$ As we and others have pointed out before, creating an environment that makes it very unattractive to stay can be counterproductive to counterterrorism, because it may cause people to disappear from, or move under, the radar, ${ }^{76}$ or promote further alienation, and possibly radicalization. ${ }^{77}$

However, the fact that expulsion or extradition is not allowed under international law, for instance because it violates human rights or when an entry ban is in place, does not necessarily mean that it does not happen in practice. Ahmed Sahnouni el-Yaacoubi, for example, was deprived of his French citizenship and expelled from France after serving a prison sentence there. Upon arrival in Morocco he was immediately detained and later sentenced to a five-year prison sentence for the same conduct he had been convicted of in France. While the ECtHR acknowledged in 2018 that his swift expulsion made it impossible to request an 'interim measure' suspending his expulsion (under Article 39 of its Rules of Court), his appeal to Article 3 was dismissed because the ECtHR ruled that the Moroccan authorities had made sufficient efforts to prevent treatment referred to in that provision. In the meantime, a Moroccan appeals court had ruled he had already served a sentence in France for the same acts and should be released..$^{78}$ In other recent case law-not concerning individuals whose nationality was revoked - we have come across examples of expulsion and extradition related to (alleged) terrorists where in hindsight a violation of Article 3 was established by the ECtHR, without severe sanctioning for the expelling country as a consequence. For example, in the case of Mohamed Ali Arous - an Algerian deported to his country of origin because he was linked to terrorism - the violation of Article 3 merely resulted in an order to the French government to obtain assurances from the Algerian government that he would not be subjected to treatment prohibited under Article $3 \cdot{ }^{79}$

75 Interview with Kamel Daoudi, conducted by researcher in 'In Limbo' project (see https:// cicj.org/research/in-limbo/) on 16 March 2017.

76 Special issue "Undesirable and Unreturnable" Aliens in Asylum and Immigration Law (above note 63); and Lutz, F. (2018), Non-removable Returnees under Union Law: Status Quo and Possible Developments, EMIL 20(1), pp. 28-52, at p. 45, who refers in this context to the concept of 'hostile environment' promoted by (at the time) UK Home Secretary Theresa May.

77 Choudhury (2017); Paulussen (2018).

78 ECtHR, A.S. v. France, judgment of 19 July 2018 , application no. $46240 / 15$.

79 ECtHR, M.A. v. France, judgment of 2 July 2018, application no. 9373/15. As for extradition; see ECtHR, Trabelsi v. Belgium, 4 September 2014, application no. 140/10; Boutagni v. 


\subsection{Deprivation Outside the Depriving State}

From the perspective of the depriving state, challenges to deal with individuals in limbo are altogether avoided if the deprivation decision is taken while the individual is outside the country. Depriving someone of citizenship while abroad will likely block his or her return and thus has the apparent advantage that the person is less likely to pose a threat domestically. Our analysis shows that most of the recent deprivation decisions (at least in Belgium, the Netherlands and the UK) are taken while the individuals are (believed to be) outside the depriving state. This development is not surprising, as de facto many of the recently convicted and/or alleged terrorists happen to be foreign fighters who (presumably) live abroad, in particular in Syria or Iraq. It suggests that in these instances citizenship deprivation is especially used to prevent the return of these foreign fighters. The UK, however, has already for yearsseemingly purposefully-deprived citizens of British citizenship while they are abroad. Indeed, the UK government is even known to wait for individuals to be abroad before it revokes their British nationality. ${ }^{80}$ In the case of a man known as 'L1', the Bureau of Investigative Journalism found evidence that the Secretary of State "deliberately waited for [L1] to leave the country before revoking his British citizenship" ${ }^{81}$ One reason why the UK uses this strategy may be that the government wants to avoid another 'Abu Hamza', whose expatriation, under the old legislation, took eight years to materialize. In the meantime, Egypt had revoked his Egyptian nationality, which made the appeals court conclude he could no longer be deprived of British citizenship as this would render him stateless. ${ }^{82}$

Some available examples show that depriving someone's citizenship while he or she is abroad complicates appeals, and may endanger the individual's personal security. The prohibition of arbitrary deprivation of citizenship under international law entails inter alia that the decision is open to effective administrative or judicial review. ${ }^{83}$ In the case of the UK it is especially problematic that the decision is effective immediately, and can be challenged only after the

France, 18 February 2011, application no. 42360/o8; and Ouabour v. Belgium, 2 June 2015, application no. $26417 / 20$.

80 Fargues $(2017,990)$.

81 Ross, A. \& Galey, P. (2014). Home Secretary waited until terror suspect was abroad before stripping citizenship, The Bureau of Investigative Journalism, London, 13 February 2014, available at https://www.thebureauinvestigates.com/stories/2014-02-13/home-secretary -waited-until-terror-suspect-was-abroad-before-stripping-citizenship. See also the case of 'M2' below.

82 Pillai \& Williams (2017: 857).

83 UN Human Rights Council (2013). Human rights and arbitrary deprivation of nationality, Report of the Secretary-General, A/HRC/25/28, 19 December 2013, Geneva: UNHCR. 
order has been made. Furthermore, the time frame to appeal a decision may be very short, and means of communication inadequate (especially if the evidence is non-public), limiting options to organize an appeal. ${ }^{84}$ Take the case of 'E2', who claims the letter containing the deprivation decision was sent to his UK address after he left for Afghanistan and Pakistan in January 2012 for family visits, and only learned of the decision in Dubai in late May, when he was on his way back to the UK and it was already too late to file an appeal. ${ }^{85}$ ' $\mathrm{K} 2$ ' submitted that he could not properly appeal his expatriation from Sudan, as he feared his communication about this would be intercepted by the Sudanese intelligence service and they would target him. ${ }^{86}$ When it comes to the person's invidual security, apart from the case of 'K2' we already mentioned, 'E2' claimed that he was in danger in Pakistan, because people knew his nationality had been revoked and this made him look guilty, while he claimed he also could not return to Afghanistan because people by then also knew his British citizenship was revoked and he was accused of working with the Taliban. ${ }^{87}$

When someone's citizenship is deprived while he stays in the state of residual nationality, he likely has legal residence there, which could mean he can continue to live there and be left alone. However, there is also a real possibility that the individual will be subjected to (another) criminal trial there (as the cases of Sahnouni and Arous show; see section 3.1), or triggers the interest of authorities of other states who may request for extradition. It is, however, also possible that the expatriated individual tries to travel independently to another third state or back to the depriving state. The citizenship of 'M2', a man born in Afghanistan who obtained British citizenship in 2011, was revoked while he was in Afghanistan in May 2014. Two months later, the man managed to travel to London via Pakistan, using his Afghan passport. While his appeal was still serving, the Special Immigration Appeals Commission (SIAC) put him under strict bail conditions in London. ${ }^{88}$

84 Zedner (2016: 234, 237).

85 Although a Special Immigration Appeals Commission (SIAC) judge concluded he was likely aware of the decision; see Galey, P. (2014). My British citizenship was everything to me. Now I am nobody - A former British citizen speaks out, The Bureau of Investigative Journalism, London, 17 March 2014, available at https://www.thebureauinvestigates.com/ stories/2014-03-17/my-british-citizenship-was-everything-to-me-now-i-am-nobody-a -former-british-citizen-speaks-out.

86 The SIAC dismissed the appeal on this point; the ECtHR agreed (see K2 v. the United Kingdom).

87 Ibid.

88 Parsons, V. (2016). Tracked by MI5 to PC world: London minicab driver 'highly probably' an Al Qaeda courier, The Bureau of Investigative Journalism, London, 22 January 2016, available at https://www.thebureauinvestigates.com/stories/2016-o1-22/tracked-by 
When the individual is in a third state at the moment of deprivation he might leave independently, be forcibly removed (extradition or expulsion), or end up in a limbo situation. ${ }^{89}$ Depending on the circumstances, independent departure from a third state is quite a likely scenario. The expatriated individual might try returning to the depriving state by irregular means, or travelling to the state of residual nationality or another third state; unless he is in detention, as we will elaborate below.

Several available examples suggest that extradition from a third state may happen, not exceptionally, under questionable circumstances. Somalian-born Mahdi Hashi, for example, was rendered stateless by the deprivation of his British citizenship, and when he crossed from Somalia into Djibouti to contact the British consulate, he was arrested by local security services and reportedly held in incommunicado detention and interrogated for three months, before being transferred to the United States to face terrorism charges. He is reported to have spent three years in pre-trial solitary confinement and in 2015 entered a guilty plea on the charge of providing material support to terrorism, for which he was sentenced to nine years. ${ }^{90}$ Another case is that of Alexanda Kotey and El Shafee Elsheikh, two of the IS militants known as 'the Beatles', who were in Iraq or Syria when their British nationality was reportedly revoked. They are currently said to be in US custody and in the process of being transferred to the US, but the legal status of such a possible transfer is unclear. ${ }^{91}$

The question of expulsion by third states to the state of residual nationality, currently comes up in particular for Turkey, Syria, Iraq and the Kurdish authorities in Northern Syria and Iraq, as they host a considerable number of expatriated European foreign fighters on territory under their control. Given that Algeria and Morocco are generally quite willing to accept individuals back (section 3.1), and that many expatriated European foreign fighters originate from those countries (section 2), it is striking to note that we have not come across a single case in which Turkey, Syria, Iraq or the Kurdish authorities

-mi5-to-pc-world-how-judges-and-theresa-may-deemed-london-minicab-driver-very -highly-probably-an-al-qaeda-courier; the SIAC decision of 22 December 2015 is available at http://siac.decisions.tribunals.gov.uk/Documents/M2-July2015.pdf.

89 Additionally, there is also the possibility the individual is tolerated or even promoted to stay, as for example happened with expatriated foreign fighters residing in IS-held territory.

$90 \quad$ K. Shamsie, 'Exiled: the disturbing story of a citizen made unBritish', The Guardian, 17 November 2018, available at https://www.theguardian.com/books/2018/nov/17/unbe coming-british-kamila-shamsie-citizens-exile.

91 B. McKernan, J. Borger \& D. Sabbagh, 'US takes custody of British Isis pair', The Guardian, 10 October 2019, available at https://www.theguardian.com/world/2019/oct/10/us -reportedly-takes-custody-of-two-british-isis-beatles. 
expelled IS fighters deprived of citizenship by a European country to Algeria or Morocco. This is not because these countries of residual nationality pertinently refuse IS fighters back. Turkey, for example, expelled two suspected IS fighters with Moroccan nationality to Morocco in $2019 .{ }^{92}$ Earlier that year Morocco itself repatriated eight foreign terrorist fighters from Syria. ${ }^{93}$ We can only speculate what explains this, but it would not be surprising if countries like Morocco and Algeria dismiss any responsibility for individuals who oftentimes are born and raised in the depriving state.

A telling and much publicized case in this regard is that of Shamima Begum, who had left the UK at the age of 15 to travel to Syria in February 2015. She was a British-born citizen and did not have dual citizenship; her parents are from Bangladesh. In February 2019 she asked for leave to return to the UK from a Syrian refugee camp, which was answered with a revocation of her British citizenship, because of her links to IS and because the Secretary of State reasoned she was entitled to Bangladeshi citizenship through her mother's descent. ${ }^{94}$ The Bangladeshi Foreign Minister told the в вс that Bangladesh would not accept her back and she was the responsibility of the UK. ${ }^{95}$ While the sIAC ruled in February 2020 that under the law and practice of the Bangladeshi government she was not stateless, it also acknowledged that she was at risk of torture or degrading treatment in the Kurdish-run Al Roj camp in Syria. ${ }^{96}$

Indeed, when independent departure or forced removal does not occur, the expatriated individuals end up in a situation of legal limbo, forcing the third state authorities to somehow deal with them. Like Begum, most of the men and women deprived of their European citizenship have so far been held in enclosed camps or detention centres, accompanied by thousands of other (European) foreign alleged IS affiliates and their children whose citizenship may not have been revoked, but who also cannot be extradited or expelled by

92 F. Tasdemir, 'Turkey deports Moroccan national for terror links', Anadolu Agency, 16 December 2019, available at https://www.aa.com.tr/en/turkey/turkey-deports-moroc can-national-for-terror-links/1675345.

93 AFP, 'Morocco repatriates eight alleged militants from Syria', Arab News, 10 March 2019, available at https://www.arabnews.com/node/1464661/middle-east.

94 S. Knight, 'If Shamima Begum, the ISIS bride, is no longer British, what does citizenship mean?', The New Yorker, 15 February 2020, available at https://www.newyorker.com/news/ letter-from-the-uk/if-shamima-begum-the-isis-bride-is-no-longer-british-what-does -citizenship-mean.

95 Shamima Begum: IS bride 'would face death penalty in Bangladesh', $B B C, 3$ May 2019, available at https://www.bbc.com/news/world-asia-48154781.

96 SIAC, Shamima Begum v. SSHD, 7 February 2020, appeal no. SC/163/2019, available at http://siac.decisions.tribunals.gov.uk/Documents/outcomes/documents/Shamima\%2O Begum\%2oOPEN\%2oJudgment\%20-\%2007.02.2020.pdf. 
the authorities holding them. They typically have no residence permit and can thus be regarded undocumented migrants. Releasing these individuals is not a viable option, as they are considered to pose a security threat. Third states, supported by the United States, have on numerous occasions called upon European countries of origin to either start extradition procedures, or cooperate in expulsion procedures, but these calls have so far largely been ignored. ${ }^{97}$ As a consequence, third states who are 'stuck' with European and other foreign fighters have taken different approaches to find a way out of this deadlock.

Under its broad anti-terrorism laws, Iraq already in 2018 started prosecuting suspected IS members, foreign fighters included. The resulting 'ten-minute trials' often lead to the death penalty and have been highly criticized for violating fair trial rights. ${ }^{98}$ After becoming exasperated by the failure to reach international agreements over what to do with them, the Kurdish authorities in Syria in February 2020 said that they too would start prosecuting foreign fighters. ${ }^{99}$ Turkey, on the other hand, in autumn 2019 started threatening that it would expel European foreign fighters to European states, even if European states were unwilling to cooperate and the suspected IS fighters' nationality had been revoked. As a Turkish official noted: "Countries can't just revoke the citizenship of such ex-terrorists and expect Turkey to take care of them; this is unacceptable to us and it's also irresponsible", adding that "Turkey is not a hotel for foreign terrorists". 100 Some commentators questioned whether deporting individuals whose citizenship was revoked was 'practically feasible,',101 while others noted that, for instance if an airline is under state control, a third country could deport such individuals despite an entry ban or in the absence of travel documents, basically presenting the depriving state with a fait accompli. ${ }^{102}$ The latter proved to be right; strong diplomatic pressure by The

97 B. Hubbard, 'Wives and Children of ISIS: Warehoused in Syria, Unwanted Back Home', New York Times, 4 July 2018, available at https:/www.nytimes.com/2018/07/04/world/ middleeast/islamic-state-families-syria.html.

98 UN Assistance Mission for Iraq (2020). Human Rights in the Administration of Justice in Iraq, Geneva: онснR, available at https:/www.ohchr.org/Documents/Countries/IQ/ UNAMI_Report_HRAdministrationJustice_Iraq_28January2o2o.pdf.

99 D. Sabbagh, 'Syrian Kurds to put Isis fighters from dozens of countries on trial', The Guardian, 6 February 2020, available at https://www.theguardian.com/world/2020/ feb/o6/syrian-kurds-to-put-isis-fighters-from-dozens-of-countries-on-trial.

100 B. McKernan, 'Turkey threatens to send foreign Isis suspects home from next week', The Guardian, 8 November 2019, available at https://www.theguardian.com/world/2019/ nov/o8/turkey-isis-suspects-repatriation-islamic-state.

101 Ibid.

102 G. Dahhan, 'Turkije kan niet zomaar alle IS'ers het land uitzetten', Trouw, 11 November 2019, availabe at https:/www.trouw.nl/binnenland/turkije-kan-niet-zomaar-alle-is-ers-het -land-uitzetten $\sim$ b664ofa5/. 
Netherlands did not prevent the deportation of Fatima H. from Turkey to the Netherlands on 19 November 2019. Interestingly the Dutch authorities had revoked her citizenship only weeks before, immediately after she had reported herself to the Dutch Embassy on 30 October 2019. In response to this illegal expulsion, the Dutch Minster of Justice and Security expressed disappointment, but also confidence to deal with the matter pragmatically: "She has not been allowed access to the Netherlands and has been put in immigration detention. The basic assumption is that, if she is prosecuted and convicted, she serves her sentence here [in the Netherlands] and will subsequently be deported to Morocco."103

\section{4}

\section{Conclusion and Discussion}

This contribution shows that the grounds for citizenship deprivation in relation to terrorist offences or national security are diverse in the five countries studied, but have in all cases expanded in recent years, and that there is a wide variety of possible scenarios expatriated individuals could end up in as a consequence. In Belgium, the Netherlands and especially the UK, the figures suggest the expanded deprivation powers have also resulted in an increase in their use, especially against foreign fighters who are (presumably) abroad. Interestingly, France has so far not followed the same trend as the other countries, although this could still change if more individuals are convicted.

Our analysis demonstrates that in cases were citizenship was revoked while the individual was inside the depriving country, this typically leads to extensive legal wrangling. If an individual successfully challenges a subsequent extradition or expulsion, or cannot be deported, this causes a legal limbo-situation, which could result in further radicalisation or drive the individuals to terrorist groups, rather than away from them. We have identified various cases where extraditions and expulsions of convicted or alleged terrorists from European states in hindsight violated the non-refoulement or ne bis in idem principles. Such breaches of human rights are in and of themselves already unacceptable, but are arguably also problematic from a counterterrorism perspective, as they can play into the hands of terrorist groups which can use them for propaganda purposes.

The increasing use of citizenship deprivation while the individual is outside of the depriving country is a worrying trend. Our analysis shows that especially

103 'Hoe Fatima H. zonder Nederlands paspoort toch naar Nederland kwam', RTL Nieuws, 20 November 2019, available at https://www.rtlnieuws.nl/nieuws/politiek/artikel/492 8791/islamitische-staat-syriestrijders-fatima-xaviera. 
in those cases, there is a risk that the expatriated individual's human rights are violated: they may not be in the position to effectively challenge the revocation decision, they may be extradited under dubious circumstances (as our examples of suspects disappearing and being held incommunicado before reappearing in the US show), or they may be prosecuted, possibly in violation of due process standards.

More specifically, the trend to revoke citizenship of individuals who currently stay in third countries is troubling from a human rights, as well as a counterterrorism perspective. If they are not detained, they may easily disappear from the radar, with the risk that neither the depriving state nor the state of residual nationality takes up the task of monitoring their whereabouts. If they are detained - as is the case for most European foreign fighters deprived of citizenship staying in Turkey, Syria or Iraq - they continue to be imprisoned in a deadlocked limbo situation with the perspective of eventually facing a possibly unfair trial in the region, or illegal expulsion back to the country of deprivation (where they might be prosecuted, but are likely to still end up in limbo eventually, either because the country or residual nationality does not want to cooperate with expulsion, or because expulsion might violate the nonrefoulement or ne bis in idem principles).

Given the above, it is questionable to what extent citizenship deprivation of individuals linked to terrorism is 'effective' in contributing to national security. If the intention is to exclude someone from society who poses a threat, the deprivation of his citizenship may from the perspective of the depriving state temporarily be an effective measure. On the longer term, however, citizenship deprivations may in less direct ways also be counterproductive as a counterterrorism approach for the depriving state. ${ }^{104}$ Although the Council of Europe stressed the importance of criminal prosecution of alleged foreign fighters, ${ }^{105}$ citizenship deprivation complicates such prosecutions. In this regard, it is telling that the Dutch prosecutor even requested the Minister of Justice and Security not to deprive dual-citizen foreign fighters of their Dutch citizenship, but to repatriate them instead. ${ }^{106}$

Judging from the responses of the Turkish, US and Kurdish authorities, citizenship deprivation - in particular while the individual stays in a third

\footnotetext{
104 Institute on Statelessness and Inclusion (2020), (note 6), p. 228.

105 Council of Europe Counter-Terrorism Strategy (2018-2022), Strasbourg: Council of Europe, available at https://search.coe.int/cm/Pages/result_details.aspx?ObjectId=o9oo oo168o8afc96.

106 W. Feenstra and A. Stoffelen, 'Justitie ziet Syriëgangers wél graag in Nederland verschijnen', De Volkskrant, 24 October 2019, available at https://www.volkskrant.nl/nieuws -achtergrond/justitie-ziet-syriegangers-wel-graag-in-nederland-verschijnen $\sim \mathrm{bd} 43 \mathrm{aba} /$.
} 
country—is likely to be judged as an insular counterterrorism approach that contradicts international solidarity. It upsets other governments, causes diplomatic tensions and may frustrate bilateral relationships with the very countries that have a strong information position in the fight against global terrorism. Citizenship deprivation has understandably been criticized as 'risk exportation. ${ }^{107}$ Unsurprisingly, there are signs that states of residual nationality and third states are increasingly refusing to accept being burdened with other states' problems. In line with Bangladesh's response to the Begum case, the Canadian government recently even accused its long-time ally the UK of "offloading its responsibilities" in the case of Jack Letts. ${ }^{108}$ If relying on other states to "clean up the mess" is the new norm, as Esbrook noted, this raises the question "what happens if all countries want to strip a threatening individual's citizenship?"109 A "race [...] to see which country can strip citizenship first", as Macklin put it, ${ }^{110}$ will not only lead to increased human rights infringements, but certainly also not benefit counter-terrorism on both national and international levels.

\section{Acknowledgements}

The authors want to thank the anonymous reviewer for the valuable feedback on an earlier version, and Caroline Opperman and Malte Stedtnitz for their assistance in writing this article.

\footnotetext{
107 Paulussen (2018).

108 Letts was deprived of British nationality while he was detained in a Syrian prison, but qualifies for a Canadian passport through his father; see D. Sabbagh, 'Jack Letts stripped of British citizenship', The Guardian, 18 August 2019, available at https:/www.theguardian .com/world/2019/aug/18/jack-letts-stripped-british-citizenship-isis-canada.

109 Esbrook (2016: 1306).

110 Macklin, A. (2015). Kick-Off Contribution, in: Macklin, A. \& Bauböck, R. (eds), The Return of Banishment: Do the New Denationalisation Policies Weaken Citizenship?, Florence: European University Institute, pp. 1-6. at p. 6.
} 